\title{
Effect of infill wall and wall openings on the fundamental period of $\mathrm{RC}$ buildings
}

\author{
A. Koçak ${ }^{1}$, A. Kalyoncuoğlu ${ }^{2} \&$ B. Zengin ${ }^{3}$ \\ ${ }^{1}$ Department of Civil Engineering, Yuldiz Technical University, Turkey \\ ${ }^{2}$ Department of Civil Engineering, Istanbul Gelisim University, Turkey \\ ${ }^{3}$ Vocational School, Istanbul Gelisim University, Istanbul, Turkey
}

\begin{abstract}
The effect of infill walls to stiffness of the structures has been known for a long time and this effect has taken many of the earthquake regulations with empirical relationships and equations into account. However, in strength-based calculations, buildings are taken as bare frames and infill walls are effected as vertical load to system, whereas infill walls contribute to stiffness at the beginning of the earthquake and help meet seismic loads by incurring damage during an earthquake.

In this study, contribution of infill walls to stiffness of the structure was analyzed in reinforced concrete framed and load-bearing buildings. Also, the effect of openings in the infill walls to stiffness was examined.

Keywords: reinforced concrete frame, infill wall, wall openings, period.
\end{abstract}

\section{Introduction}

A large number of buildings are constructed with infill walls in Turkey. Infill walls are constructed for divide the interior area of buildings. These walls are ignored on design and calculation of buildings due to modelling of infill walls are hard and complex. Effect of the infill walls are modelled as mass and weight which are applied to floors or beams as a static load. However, effects of the infill walls are taken into consideration with some coefficients which calculated by using some experiential formulas in some country regulations. It is well known that there are a lot of effects of infill walls on behavior of structures under earthquake and vertical loads and dynamics properties like stiffness, fundamental 
period and damping. Infill walls enhance the lateral behavior of the frames they fill up.

For simplify the effect of infill wall on behavior of frame system, a lot of research have been made in years. The first study about behavior of frames with infill wall was examined by the Polyakov [1] in 1956. After Polyakov, Holmes [2] proposed replacing the panel by an equivalent diagonal strut with same material as the infill. Width of this equivalent diagonal strut is determined as $1 / 3$ of the infill diagonal length. Smith [3] and Smith and Carter [4] has developed furthermore the idea of Holmes's equivalent strut, and suggested two pinconnected equivalent diagonal struts related the width of the equivalent diagonal strut to the infill/frame contact lengths using an analytical equation. In 1971, based on experimental and analytical data, Mainstone [5] proposed an empirical equation for the calculation of the equivalent strut width of infill walls on frames by using stiffness and strength of infilled frames. These equations was changed by Mainstone and Weeks [6] and Mainstone [7] later and this formula was included in FEMA-274 (Federal Emergency Management Agency 1997) [8] for the analysis and rehabilitation of buildings as well as in FEMA-306 (Federal Emergency Management Agency 1998) [9] and Turkish Seismic Code of 2007 [10], as it has been proven to be the most popular over the years. Decanini and Fantini [11] changed suggested another experimental formula which using same idea with Stafford Smith. 1/4 of the infill diagonal length for equivalent diagonal strut width, which were assumed as all stresses was carried by infill wall before horizontal joint deformation, was suggested by Paulay and Priestley [12] in 1992. Durrani and Luo [13] suggested some equations by using $\mathrm{\gamma}$ and $\mu$ coefficients which were affected by properties of beams, columns and walls.

Also some other studies were carried out to investigate effect of infill wall on frames. Govindan et al. [14] found twice as high bearing capacity of infilled walls, five times higher rigidity and 2.6 times smaller displacement ratio at the top of the frame. Govindan et al. [14] subjected cyclic loads to two different 7 storey buildings with infill walls and bare frames. They calculated and compared the horizontal rigidity, ductility and energy dissipation capacities of infill walls and frames. Dowrick [15] concluded that infill walls did increase the structural strength and rigidity. Aytun [16] and Bayülke [17], on the other hand, stated that infill walls decreased the building periods while also increasing the rigidity of the system. Altın et al. [18] reported an increase of 6 to $28 \%$ of the initial rigidity if a whole connection between the infill wall and the frames are considered. Mehrabi et al. [19] conducted experiments on bricks with and without hollow spaces and concluded that when vertical loads on the infill walls are increased, then the total horizontal bearing capacity of the composite frame also increases by $25 \%$. Mehrabi et al. [19] and Asteris [20] observed the effects of reinforced concrete framed infill walls at earthquake conditions and the effects of infill walls with or without the door and window openings. They concluded that frames with door and window openings are less rigid and have higher periods than those without any openings. Mostafaei and Kabeyasawa [21] achieved three dimensional non-linear time history analyses for both bare frame and infilled frame in order to obtain an analytical answer for the performance of an existing 
building and an approach was developed to model masonry infill walls with or without opening. On the other hand, Amanat and Hoqueb [22] observed that, the beam and column stiffness have negligible effect on the period. This study also shows that randomness in the distribution of infill does not have a significant effect on the period; instead, it is the total amount of infill that is important. Puglisi et al. [23] proposed a model for the behavior of infill panels in framed structures which is based on the equivalent strut model, the plastic concentrator concept, and damage mechanics. Güler et al. [24] performed a numerical analysis of data collected from an experimentally vibrated building, in which infill walls were defined as diagonal compression struts. Güney et al. [25] studied effect of nonlinear behavior of infill walls on symmetric and asymmetric structures. Budak [26] observed effect of infill walls on structural loads. Kocak and Y1ldirım [27] studied effects on infill wall ratio on the period of reinforced concrete framed buildings and an equation for obtain for structural fundamental period is suggested.

Masonry walls contribute to the stiffness of the infill under the lateral load. The term 'infilled frame' is used to denote a composite structure which combination of a moment resisting plane frame and infill walls. The composite behavior of an infilled frame imparts lateral stiffness and strength to the building. The typical behavior of an infilled frame subjected to lateral load is illustrated in Figures 1(a) and (b).
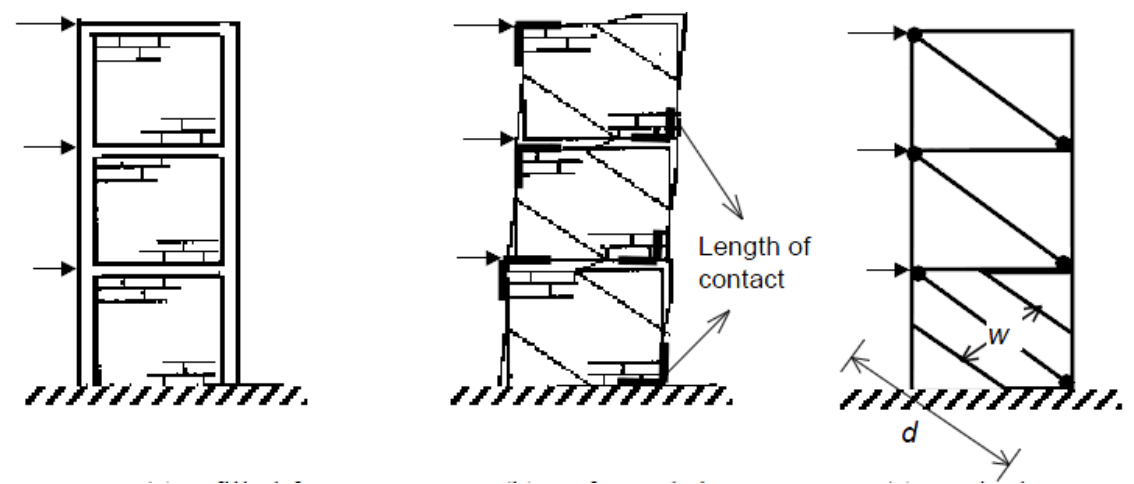

Figure 1: The typical behavior of an infilled frame subjected to lateral load [28].

In this study, a 1-storey building with one opening is taken into account and effect of the infill walls opening on system is investigated, firstly. Then, equivalent strut model is suggested for each system with different openings. At the second part, 3, 6, 9 and 11-storey buildings are taken into consideration and suggested strut models are used for each one. In this way effect of the openings on infill wall is examined and a coefficient for equivalent strut with openings $(\beta)$ is suggested. Then, resulting period values are compared with the other literature sources. 


\section{Equivalent strut models for infilled frames}

There are a lot of models in literature for modelling infilled walls as an equivalent strut frames but, Mainstone which suggested by Turkish Seismic Code, FEMA-274 and FEMA-306, is used for this study. In this method, first stiffness parameters are determined by using eqn. (1) and equivalent strut width is determined by using eqn. (2). Then equivalent strut width, w, is implemented the frame model with a single diagonal strut which have width as $\mathrm{w}$ and thickness as $\mathrm{t}$.

$$
\begin{gathered}
\lambda h=\left[h_{\text {column }} \times \sqrt[4]{\frac{E_{\text {wall }} \times t_{\text {wall }} \times \sin 2 \theta}{4 \times E_{\text {column }} \times I_{\text {column }} \times h_{\text {wall }}}}\right] \\
w=0.175 \times(\lambda h)^{-0.4} \times d
\end{gathered}
$$

Figure of infill wall and equivalent strut models are given in figure 2.

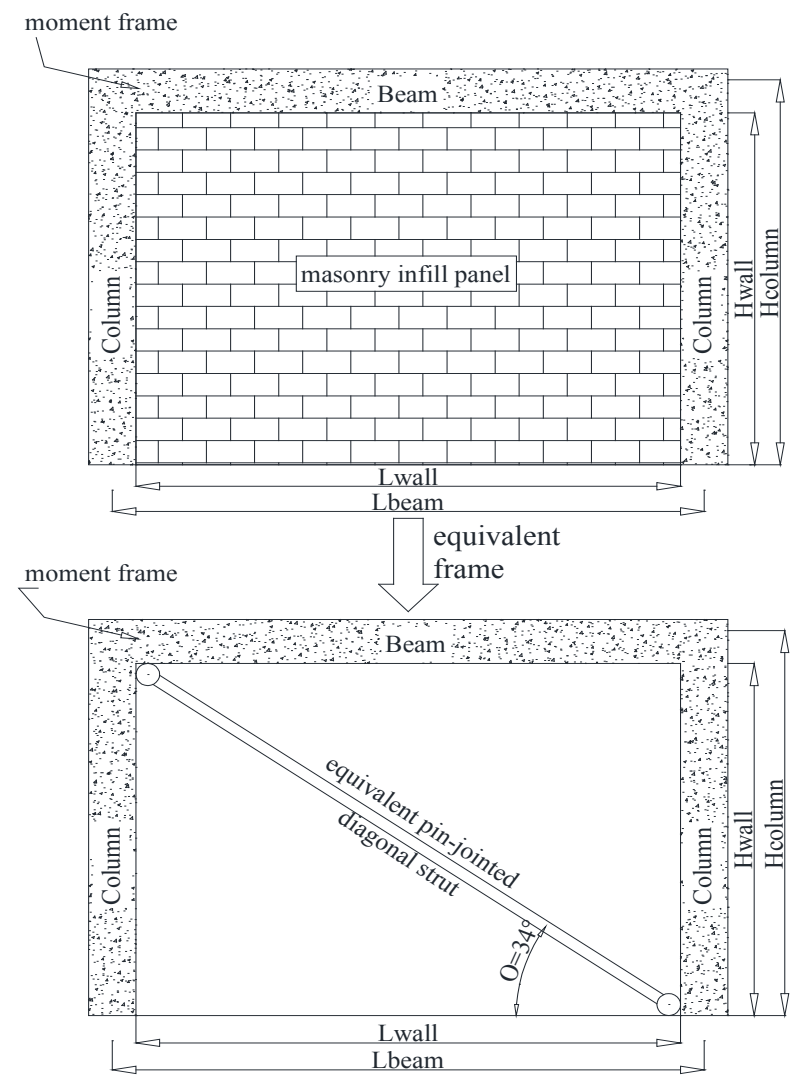

Figure 2: $\quad$ Equivalent strut model for masonry infill walls. 
Then two different fully closed reference model is made up. First model is created with shell element (denoted as $\mathrm{SH}$ ) while the second one equivalent pinjointed diagonal strut (denoted as EF). Thickness of the wall in $\mathrm{SH}$ is taken as $0.25 \mathrm{~m}$ and equivalent pin-jointed diagonal strut width is found as $0.516 \mathrm{~m}$ by using eqn. (1) and eqn. (2).

Table 1: $\quad$ Properties of infill wall and moment frame elements [24].

\begin{tabular}{|c|c|c|c|c|}
\hline & \multicolumn{3}{|c|}{ Modulus of Elasticity (MPa) } \\
\hline & & $\mathrm{E}_{\mathrm{PER}}$ & $\mathrm{E}_{\mathrm{PAR}}$ & $\mathrm{E}_{\mathrm{AVE}}$ \\
\hline \multirow{2}{*}{ Infill Wall } & Without Plaster & 2500 & 4600 & 3550 \\
\hline & With Plaster & 4200 & 7800 & 6000 \\
\hline \multicolumn{2}{|c|}{ Beam (Concrete) } & \multicolumn{3}{|c|}{30250} \\
\hline \multicolumn{2}{|c|}{ Columns (Concrete) } & \\
\hline
\end{tabular}

The experimental values of the modulus of elasticity of directions parallel (Epar) and perpendicular (Eper) to the holes of the bricks are given in table 1 . Average modulus elasticity value for infill wall with plaster is taken into account in this study. Average compressive strength of the concrete, which used for beams and columns and infill wall are taken as $25 \mathrm{MPa}$ and $2.5 \mathrm{MPa}$, respectively.

\section{Determination of modulus of elasticity coefficient}

For determination of modulus of elasticity coefficient both models are subjected to modal analysis which is using for determine the natural mode shapes and frequencies of a structure during free vibration by using SAP2000 14.2.4 [29]. Then fundamental period of the structures are found by using frequencies. Thereafter, this procedure is applied to six different opening scenarios so different modulus of elasticity coefficients $(\beta)$ are achieved for equivalent pin-

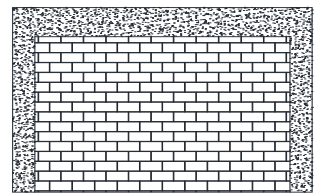

a) $\beta=1.00$

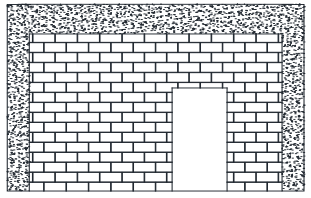

d) $\beta=0.52$

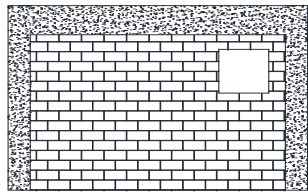

b) $\beta=0.90$

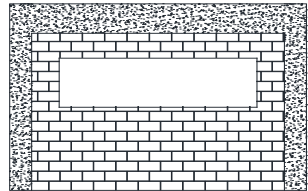

e) $\beta=0.23$

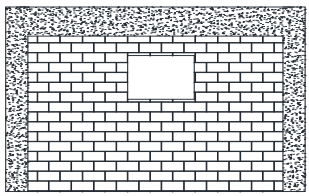

c) $\beta=0.79$

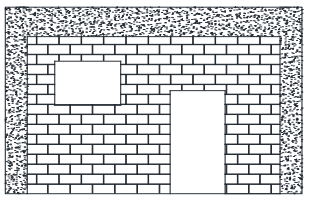

f) $\beta=0.41$

Figure 3: Different opening scenarios for infill wall. a) fully closed, b) small windows, c) small windows at middle, d) door, e) large window, f) small windows and door. 
jointed diagonal strut models. Figures and calculated modulus elasticity coefficients $(\beta)$ of different opening scenarios are given in figure 3 .

\section{Numerical analysis and results}

The considered buildings are modeled according to the condition that infill walls existed under all of the frames except entrance floor, and then the analyses are repeated with the different wall opening scenarios. Typical floor plan of model is given in figure 4.

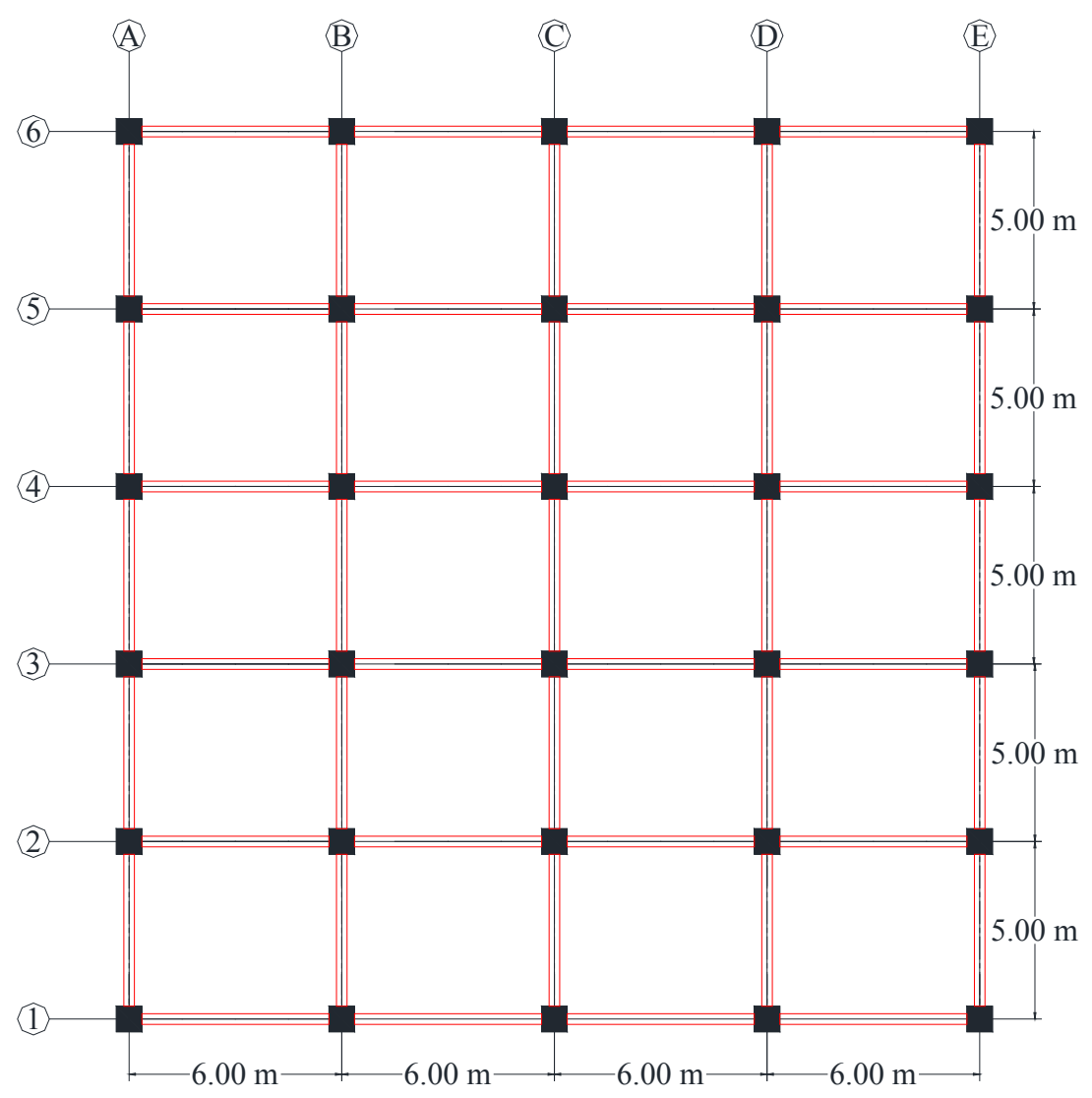

Figure 4: Typical floor plan of fully closed wall model.

The analysis is conducted for 6 different combinations of outer and inner infill walls and is given in table 3. Each model is created in ETABS 3D Analysis of Building Systems 9.7.48 [30] then fundamental period results is taken after modal analysis. Each scenario is repeated for 3, 6, 9 and 11-storey buildings. Size of the columns, which $45 \mathrm{~cm} \times 45 \mathrm{~cm}$ at basement, is decreased with the 
storey height while the all beams and walls have $35 \mathrm{~cm} / 40 \mathrm{~cm}$ sizes and $25 \mathrm{~cm}$ thicknesses, respectively.

Table 2: Analysis combination and modulus of elasticity values for outerinner infill walls.

\begin{tabular}{|l|l|l|c|c|}
\hline Cases & Exterior Infill Wall & $\begin{array}{c}\text { Interior Infill } \\
\text { Wall } \\
\text { Elasticity } \\
\text { of Exterior } \\
\text { Infill Wall } \\
\mathbf{( M P a )} \\
\boldsymbol{\beta} \times \mathbf{E S H}\end{array}$ & $\begin{array}{c}\text { Modulus } \\
\text { Elasticity } \\
\text { of Interior } \\
\text { Infill Wall } \\
\mathbf{( M P a )} \\
\boldsymbol{\beta} \times \mathbf{E S H}\end{array}$ \\
\hline Case \#1 & Fully Infilled & Fully Infilled & 15150 & 15150 \\
\hline Case \#2 & Fully Infilled & Door & 15150 & 7945 \\
\hline Case \#3 & Small Window & Door & 13671 & 7945 \\
\hline Case \#4 & Small Window at Center & Door & 11990 & 7945 \\
\hline Case \#5 & Large Window & Door & 3479 & 7945 \\
\hline Case \#6 & \multicolumn{2}{|c|}{ Bare Frame } & 6000 & 6000 \\
\hline
\end{tabular}

Analysis results and calculated fundamental period values is given in table 4 . According to the table, it is obvious that infill walls increase the stiffness of buildings and effects to behavior of the structures remarkably in a positive way. Openings in infill walls like door or windows reduce the stiffness and resulted as higher fundamental period values.

Table 3: Analysis results, changing of fundamental period due to case types and storey number.

\begin{tabular}{|l|c|c|c|c|c|c|c|c|}
\cline { 2 - 9 } \multicolumn{1}{c|}{} & \multicolumn{2}{c|}{ 3-Storeys } & \multicolumn{2}{c|}{ 6-Storeys } & \multicolumn{2}{c|}{ 9-Storeys } & \multicolumn{2}{c|}{ 11-Storeys } \\
\cline { 2 - 9 } \multicolumn{1}{c|}{} & $\mathbf{T x}(\mathbf{s})$ & $\mathbf{T y}(\mathbf{s})$ & $\mathbf{T x}(\mathbf{s})$ & $\mathbf{T y}(\mathbf{s})$ & $\mathbf{T x}(\mathbf{s})$ & $\mathbf{T y}(\mathbf{s})$ & $\mathbf{T x}(\mathbf{s})$ & $\mathbf{T y}(\mathbf{s})$ \\
\hline Case \#1 & 0.117 & 0.112 & 0.224 & 0.216 & 0.342 & 0.329 & 0.424 & 0.409 \\
\hline Case \#2 & 0.140 & 0.130 & 0.263 & 0.248 & 0.395 & 0.373 & 0.485 & 0.460 \\
\hline Case \#3 & 0.142 & 0.133 & 0.269 & 0.254 & 0.403 & 0.381 & 0.493 & 0.469 \\
\hline Case \#4 & 0.146 & 0.137 & 0.275 & 0.261 & 0.412 & 0.391 & 0.504 & 0.480 \\
\hline Case \#5 & 0.169 & 0.167 & 0.321 & 0.314 & 0.476 & 0.464 & 0.579 & 0.566 \\
\hline Case \#6 & 0.527 & 0.502 & 0.914 & 0.866 & 1.220 & 1.115 & 1.351 & 1.282 \\
\hline
\end{tabular}

These fundamental period values which found from analysis compared with the equations in literature. Güler et al. proposed eqn. (3) where $\mathrm{H}(\mathrm{m})$ is the height from base to roof in meter., to determine the period considering the effect of the infill wall according to building height.

$$
T_{A}=0.026 \times H^{0.9}
$$

Chopra and Goel [31] have also proposed an expression for moment resisting frame buildings that is given in eqns (4) and (5). 
128 Earthquake Resistant Engineering Structures IX

$$
\begin{aligned}
& T_{L C}=0.047 \times H^{0.9} \\
& T_{U C}=0.067 \times H^{0.9}
\end{aligned}
$$

In Eurocode 8 [32], another period-height relationship is suggested for uncracked infilled RC buildings.

$$
T_{A}=0.075 \times H^{0.75}
$$

Also another analytical period-height relationship is examined by Crowley and Pinho [33], for RC buildings bare frames $\left(\mathrm{T}_{\mathrm{BF}}\right)$, fully infilled frames $\left(\mathrm{T}_{\mathrm{FIF}}\right)$ and frames with openings $\left(\mathrm{T}_{\mathrm{FWO}}\right)$.

$$
\begin{gathered}
T_{B F}=0.054 \times H \\
T_{F I F}=0.025 \times H \\
T_{F W O}=0.034 \times H
\end{gathered}
$$

\begin{tabular}{|c|c|c|c|c|c|c|c|c|}
\hline & \multicolumn{2}{|c|}{ 3-Storeys } & \multicolumn{2}{|c|}{ 6-Storeys } & \multicolumn{2}{|c|}{ 9-Storeys } & \multicolumn{2}{|c|}{ 11-Storeys } \\
\hline & $\mathrm{Tx}(\mathrm{s})$ & $\mathrm{Ty}(\mathrm{s})$ & $\mathrm{Tx}(\mathrm{s})$ & Ty(s) & $\operatorname{Tx}(\mathrm{s})$ & $\mathrm{Ty}(\mathrm{s})$ & $\operatorname{Tx}(\mathrm{s})$ & Ty(s) \\
\hline Case \#1 & 0.117 & 0.112 & 0.224 & 0.216 & 0.342 & 0.329 & 0.424 & 0.409 \\
\hline Case \#2 & 0.140 & 0.130 & 0.263 & 0.248 & 0.395 & 0.373 & 0.485 & 0.460 \\
\hline Case \#3 & 0.142 & 0.133 & 0.269 & 0.254 & 0.403 & 0.381 & 0.493 & 0.469 \\
\hline Case \#4 & 0.146 & 0.137 & 0.275 & 0.261 & 0.412 & 0.391 & 0.504 & 0.480 \\
\hline Case \#5 & 0.169 & 0.167 & 0.321 & 0.314 & 0.476 & 0.464 & 0.579 & 0.566 \\
\hline Case \#6 & 0.527 & 0.502 & 0.914 & 0.866 & 1.220 & 1.115 & 1.351 & 1.282 \\
\hline $\begin{array}{l}\text { Güler et al. } \\
\text { [24] (eqn. } \\
\text { (3)) }\end{array}$ & \multicolumn{2}{|c|}{0.188} & \multicolumn{2}{|c|}{0.351} & \multicolumn{2}{|c|}{0.505} & \multicolumn{2}{|c|}{0.605} \\
\hline $\begin{array}{l}\text { Chopra and } \\
\text { Goel [31] } \\
\text { (eqn. (4)) }\end{array}$ & \multicolumn{2}{|c|}{0.340} & \multicolumn{2}{|c|}{0.634} & \multicolumn{2}{|c|}{0.913} & \multicolumn{2}{|c|}{1.093} \\
\hline $\begin{array}{l}\text { Chopra and } \\
\text { Goel [31] } \\
\text { (eqn. (5)) }\end{array}$ & \multicolumn{2}{|c|}{0.484} & \multicolumn{2}{|c|}{0.903} & \multicolumn{2}{|c|}{1.301} & \multicolumn{2}{|c|}{1.559} \\
\hline $\begin{array}{l}\text { Eurocode } \\
8(\text { eqn. }(6))\end{array}$ & \multicolumn{2}{|c|}{0.390} & \multicolumn{2}{|c|}{0.655} & \multicolumn{2}{|c|}{0.888} & \multicolumn{2}{|c|}{1.033} \\
\hline $\begin{array}{l}\text { Crowley and } \\
\text { Pinho [33] } \\
\text { (eqn. (7)) } \\
\end{array}$ & \multicolumn{2}{|c|}{0.486} & \multicolumn{2}{|c|}{0.972} & \multicolumn{2}{|c|}{1.458} & \multicolumn{2}{|c|}{1.782} \\
\hline \begin{tabular}{|l|} 
Crowley and \\
Pinho \\
{$[33]($ eqn. (8)) }
\end{tabular} & \multicolumn{2}{|c|}{0.225} & \multicolumn{2}{|c|}{0.450} & \multicolumn{2}{|c|}{0.675} & \multicolumn{2}{|c|}{0.825} \\
\hline $\begin{array}{l}\text { Crowley and } \\
\text { Pinho [33] } \\
(\text { eqn. (9)) }\end{array}$ & \multicolumn{2}{|c|}{0.306} & \multicolumn{2}{|c|}{0.612} & \multicolumn{2}{|c|}{0.918} & \multicolumn{2}{|c|}{1.122} \\
\hline
\end{tabular}

According to analytical equations and infill wall scenarios fundamental period of the buildings with 3, 6, 9, 11-storey are calculated and given in table 4 and figure 5 .

Table 4: Analysis results, changing of fundamental period due to case types, analytical equation and storey number. 


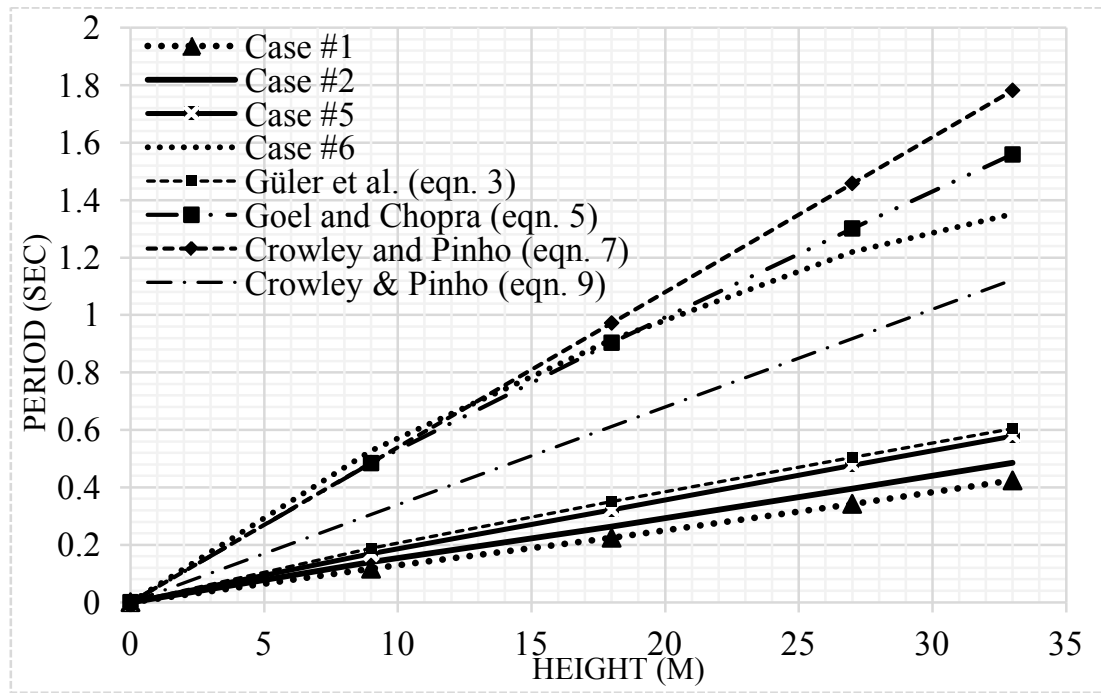

Figure 5: Period-height relationship of different infill wall cases and analytical equations.

\section{Conclusion}

Infill walls decrease the fundamental period of the structure and increase the stiffness as can be seen from the studies above. On the other hand, some openings in the infill wall like window, door openings affect the infill wall stiffness and increase the fundamental period of the building. Also, it is obviously seen that some analytical equations in country regulations and codes are mostly suitable for the structures which close to the frame system with low infill wall stiffness.

In brief, there is

- $\quad 78 \%-68 \%$ decreasing between fundamental period values of bare frame and fully infilled frame.

- $18 \%-13 \%$ decreasing between infilled frame with window-door openings buildings and fully infilled frame buildings.

\section{References}

[1] Polyakov, S.V., On the Interactions between masonry filler walls and enclosing frame when loaded in the plane on the wall, Translations in Earthquake Engineering, Research Institute, Moscow, 1956.

[2] Holmes H., Steel frames with brickwork and concrete infilling. Proceedings of the Institute of Civil Engineers, 19, pp. 473- 478, 1961.

[3] Smith, B.S., Behaviour of the square infilled frames. Journal of Structural Div. ASCE, 92, pp. 381-403, 1966. 
[4] Smith, B.S. and Carter, C., A method of analysis for infilled frames, Proc., Instn. Civ. Engrs., 44, pp. 31-48, 1969.

[5] R.J. Mainstone, On the stiffnesses and strengths of infilled frames, Proc. Inst. Civ. Engrs., Supp. (iv), pp. 57-90, 1971.

[6] R.J. Mainstone, and G.A. Weeks, The influence of bounding frame on the racking stiffness and strength of brick walls, Proceedings of the $2^{\text {nd }}$ International Brick Masonry Conference, Building Research Establishment, Watford, England, pp. 165-171, 1970.

[7] R.J. Mainstone, Supplementary note on the stiffness and strengths of infilled frames, Current Paper CP 13/74, Building Research Station, Garston, Watford, U.K, 1974.

[8] Federal Emergency Management Agency, NEHRP Commentary on the Guidelines for the Seismic Rehabilitation of Buildings, FEMA-274, Applied Technology Council, Washington, DC, 1997.

[9] Federal Emergency Management Agency, Evaluation of earthquake damaged concrete and masonry wall buildings: basic procedures manual, FEMA-306, Applied Technology Council, Washington, DC. 1998.

[10] Ministry of Public Works and Settlement, Specification for buildings to be Constructed in Seismic Zones, TSC-2007, Ankara, Turkey. 2007.

[11] Decanini LD, Fantin GE. Modelos simplificados de la mamposteria incluida en porticos, Caracteristicas de rigidez y resistencia lateral en estado limite, Jornadas Argentinas de Ingenieria Estructural, Buenos Aires, Argentina, 2, pp. 817-836, 1986.

[12] Paulay T., Priestley M.J.N., Seismic Design of Reinforced Concrete and Masonry Buildings, John Wiley \& Sons, New York, 1992.

[13] Durrani AJ, Luo YH., Seismic Retrofit of Flat-slab Buildings with Masonry Infills, NCEER workshop on seismic response in Masonry Infills, National Center for Earthquake Engineering Research, Technical Report NCEER94-0004, 2004.

[14] Govindan, P., Lakshmipathy, M. and Santhakumar, A. R., Ductility of Infilled Frames, Journal of American Concrete Institute, July-August, pp. 567-576, 1986.

[15] Dowrick, D.J., Earthquake Resistant Design for Engineers and Architects, John Wiley \& Sons, New York, 1987.

[16] Aytun, A., The Experimental Measurement of Structures' Natural Vibration Periods, Türkiye' de Deprem Sorunu ve Deprem Mühendisliği Sempozyumu, Ankara, 1972.

[17] Bayülke, N., What is Period of a Structure? Which period of structure should be used during the design phase, Turkish Chambers of Civil Engineers, Ankara Şubesi Bülteni, Ankara, 1998.

[18] Altın, S., Ersoy, U. and Tankut, T., Hysteretic Response of Reinforced Concrete Infilled Frames, Journal of Structural Engineering, 118(8), pp. 2133-2150, 1992.

[19] Mehrabi, A., Shing, P. B., Schuller, M.P. and Noland, J.L., Experimental Evaluation of Masonry Infilled RC Frames, Journal of Structural Engineering, 122(3), pp. 228-237, 1996. 
[20] Asteris, P.G., Lateral Stiffness of Brick Masonry Infilled Plane Frames, Journal of Structural Engineering, ASCE, 129(8), pp. 1071-1079, 2003.

[21] Mostafaei, H., and Kabeyasawa, T., Effect of Infill Masonry Walls on the Seismic Response of Reinforced Concrete Buildings Subjected to the 2003 Bam Earthquake Strong Motion: A Case Study of Bam Telephone Center Bull. Earthq. Res. Inst. Univ. Tokyo, 79, pp. 133-156, 2004.

[22] Amanat, K.M. and Hoqueb, E., A rationale for determining the natural period of RC building frames having infill, Engineering Structures, 28(4), pp. 495-502, (2006).

[23] Puglisi, M., Uzcategui, M. and Flórez-López, J., Modeling of masonry of infilled frames, Part II: Cracking and damage, Engineering Structures, 31(1), pp. 119-124, 2009.

[24] Güler, K., Yüksel, E. and Koçak, A., Estimation of the Fundamental Vibration Period of Existing RC Buildings in Turkey Utilizing Ambient Vibration Records, Journal of Earthquake Engineering, 12(S2), pp. 140$150,2009$.

[25] Güney D., Boduroğlu, M.H., Aydın, E., Nonlinear effect of the infill walls on symmetrical and asymmetrical structures, Sixth International Advances on Civil Engineering Conference, Boğaziçi University, 2004.

[26] Budak, A., Effect of Infill Walls on Structural Earthquake Loads, Seventh International Advances on Civil Engineering Conference, Y1ldı Technical University, Turkey, 2006.

[27] Kocak. A., Yıldırım, M.K., Effects of Infill Wall Ratio on the Period of Reinforced Concrete Framed Buildings, Advances in Structural Engineering, 14(5), 2011.

[28] Govindan, P., Composite Action and Ductility of Reinforced Concrete Frames with Brick Infill, Ph.D Thesis, College of Engineering, Anna University, Chennai, 1986.

[29] Sap2000 14.2.4., Structural Analysis Program, Computer and Structures, Inc.

[30] ETABS 9.7.4., Extended 3D Analysis of Building Systems.

[31] Chopra, A.K. and Goel, R.K., Building Period Formulas for Estimating Seismic Displacements, Earthquake Spectra, 16(2), pp. 533-536, 2000.

[32] Comite Europeen de Normalisation, Eurocode 8, Design of Structures for Earthquake Resistance - Part 1:General Rules, Seismic Actions and Rules for Buildings, Pr-EN 1998-1, Final Draft, December 2003.

[33] Crowley, H., Pinho, R., Simplified Equations for Estimating the Period of Vibration of Existing Buildings, First European Conference on Earthquake Engineering and Seismology, Switzerland, 2006. 